\title{
FROM ABUSE TO BASE EROSION, HOW DID IT COME TO THIS?1
}

\section{Frans Vanistendael}

\section{A. A SHORT INTRODUCTION}

B. ABUSE OF COMMUNITY LAW

C. TAX AVOIDANCE AS A JUSTIFICATION FOR MEASURES RESTRICTING THE FUNDAMENTAL FREEDOMS

1. Extending justifications to 'fiscal supervision' under the Rule of Reason

2. Initial rejection by the CJEU of tax avoidance as justification

3. Marks \& Spencer, the turning point

D. TAX AVOIDANCE AS ABUSE OF COMMUNITY LAW

1. Abuse of Community law in customs $\mathbf{1 . 2 0}$

2. Halifax: abuse of law is an interpretation principle of EU law

3. Cadbury Schweppes: limiting tax avoidance to abuse of Community law

4. Variations in the wording of CJEU case law after Cadbury Schweppes

E. TRADITIONAL FORMULATION OF ANTI-AVOIDANCE RULES IN EU DIRECTIVES
1.1 1. Two formulas of traditional formulation of anti-avoidance rules 1.34

2. The reference to national and agreement based rules

3. The reference to 'the principal objective or one of the principal objectives'

4. Conclusion on traditional antiavoidance rules

F. BEPS: THE DIFFERENCE BETWEEN BASE EROSION AND TAX AVOIDANCE

1. The key indicators of the new approach

2. The new objective of tax conventions

3. New BEPS rules for treaty benefits 1.46

G. NEW TAX AVOIDANCE RULES IN EU DIRECTIVES $\quad 1.50$

1. A conventional start before BEPS $\quad 1.50$

2. The impact of BEPS in the Parent-Subsidiary Directive $\quad 1.51$

3. GAAR in ATAD 1.56

4. The interpretation of GAAR in ATAD 1.60

\section{A. A SHORT INTRODUCTION}

This chapter is the story of anti-avoidance in EU tax law from the very beginning until today. It starts with the concept of 'abus de droit', i.e. the idea

1 This chapter is based on a seminar held at the University of Luxembourg on 15 February 2019. At that time, the decision in what is now called the Danish tax cases of 26 February 2019 was not yet known. Therefore this chapter does not deal with the concept of abuse in EU tax law as it has been commented in the articles written posterior to these decisions, see paragraph 1.37 in fine. 
that a person may abuse his rights which he has under the law, as it was developed in French case law under the Civil Code of 1804. ${ }^{2}$ That concept, which spread in many different areas of civil law, also found its way into European communitarian law through the case law of the Court of Justice of the European Union (CJEU). That concept which developed into a pillar of EU communitarian law finally ended up in customs duties, VAT and income taxation as a principle restricting the unlimited exercise of the fundamental freedoms under the Treaty of the Functioning of the European Union (TFEU).

1.2 The second source of anti-avoidance doctrine in EU tax law has its origin in the argumentation used by the Member States as a justification for restrictions imposed on the same fundamental freedoms by national law. In the famous Cassis de Dijon case, the CJEU held that:

Obstacles to movement within the Community resulting from disparities between the national laws relating to the marketing of products in question must be accepted in so far as those provisions may be recognized as being necessary in order to satisfy mandatory requirements relating in particular to the effectiveness of fiscal supervision, the protection of public health, the fairness of commercial transactions and the defence of the consumer. ${ }^{3}$

This reference by the Court to fiscal supervision has been used by national tax administrations to defend anti-avoidance measures in taxation.

1.3 Finally, the EU legislator has also introduced anti-avoidance measures in tax directives. The first income tax directive on cross-border dividends contained a specific article permitting Member States to apply national and treaty based provisions required for the prevention of fraud or abuse. ${ }^{4}$ At the same date the EU legislator approved the merger directive containing a specific anti-abuse clause allowing Member States to refuse the tax benefits of the directive when the merger 'has as its principal objective or one of its principal objectives tax evasion or tax avoidance. ${ }^{5}$

2 Court of Appeal, Colmar, 02.05.1856, Dalloz Périodique 1856, 2, 9: 'l'exercice de tout droit doit avoir pour limite la satisfaction d'un intérêt sérieux et légitime'. That decision started a whole school of thought in France on 'abuse of law', see L. Josserand, De l'abus des droits, Librairie nouvelle de droit et de jurisprudence (1905) and L. Campion, La théorie de l'abus des droits (Emile Bruylant, 1925).

3 Case 120/78 Rewe-Zental AG v Bundesmonopolverwaltung für Branntwein, ECLI:EU:C:1979:42 (hereafter 'Cassis de Dijon'), para. 8.

4 Council Directive 90/435/EEC of 23 July 1990 on the common system of taxation applicable in the case of parent companies and subsidiaries of different Member States [1990] OJ L225/6 (repealed), Article 1(2).

5 Council Directive 90/434/EEC of 23 July 1990 on the common system of taxation applicable to mergers divisions, transfers of assets and exchanges of shares concerning companies of different Member States [1990] OJ L225/1 (repealed), Article 11. 
Already more than a quarter of a century ago there were not less than four different strands of anti-avoidance doctrine at work in European communitarian law in general: (1) a general abuse of law doctrine that came to life in the 1970s; (2) a doctrine justifying restrictions of the fundamental freedoms on the basis of the effectiveness of fiscal supervision including the fight against tax avoidance and evasion; (3) a specific permission in the parent-subsidiary directive to apply national and treaty based anti-avoidance and anti-evasion measures; and (4) a specific provision in the merger directive allowing to refuse benefits where tax avoidance and tax evasion constituted one of the principal objectives of a cross-border business reorganisation. It took the European Court of Justice some time to bring order in these disparate concepts and doctrines and to reach a balance between the rightful application of the fundamental freedoms on the one hand and the legitimate budgetary interests of the Member States in protecting their national tax laws on the other. That balance was reached more or less in 2006 in the cases Halifax for VAT 6 and Cadbury Schweppes ${ }^{7}$ for income tax. In the latter case the CJEU decided that there was only abuse of the fundamental freedoms and therefore abuse in the sense of tax avoidance, justifying a restrictive tax measure when the taxpayer was involved in 'the creation of wholly artificial arrangements which do not reflect economic reality'. ${ }^{8}$

That delicate balance between the protection of the fundamental freedoms and the national budgetary interests of the Member States was challenged by the many international tax scandals exposing abuse of tax law by multinational companies. ${ }^{9}$ In February 2013 the Organisation for Economic Co-operation and Development (OECD) issued its report on Base Erosion and Profit Shifting (BEPS). On 5 October 2015 it issued 15 points of its BEPS action plan and on 1 January 2017 it opened the Multilateral Instrument (MLI) as a Convention for signature with the avowed purpose to eliminate international double non-taxation and undue reduction of tax burdens. The European Commission fully embraced the OECD approach and proposed a series of draft directives to implement in all the Member States several of the BEPS actions: introducing an exit tax, a Controlled Foreign Companies (CFC) regime, General Anti-avoidance Rules (GAAR) formulated like a Principal Purpose Test (PPT), a special regime for hybrids, a CBC system and automatic exchange rules for cross-border rulings and mandatory reporting for

6 Case C-255/02 Halifax and Others (2006) ECLI:EU:C:2006:121.

7 Case C-196/04 Cadbury Schweppes and Cadbury Schweppes Overseas (2006) ECLI:EU:C:2006:544.

8 Ibid. para. 55.

9 For instance, the so-called UBS banking scandal in the US, the so-called Luxleaks scandal, the so-called Panama papers scandal, as well as the numerous State-aid cases initiated by the European Commission, partially in the wake of these scandals. 
intermediaries on reportable cross-border arrangements. The EU Council of ministers approved all these directives with lightning speed. ${ }^{10}$

1.6 At this stage it is not clear how all these legislative changes will have to be accommodated within the balance of CJEU case law between the protection of the fundamental economic freedoms in the TFEU and the protection of the budgetary interest in the national tax systems of the Member States. It is also too early to tell how the European Court of Justice will react to the clear shift in EU legislation from a judgment based on an analysis of all facts and circumstances of each individual case of tax avoidance to a more general approach of characterising a category of arrangements as base erosion on the base of certain indications or hallmarks. The purpose of this chapter is to make clear what is the difference between abuse and base erosion and how the approach of BEPS poses a formidable challenge to the exercise of the fundamental freedoms in the EU.

\section{B. ABUSE OF COMMUNITY LAW}

1.7 Long before the discussion of tax avoidance cropped up in CJEU case law as a justification for restricting the fundamental economic freedoms, the concept of abuse of Community law was introduced as a limitation to the exercise of those freedoms. The first case to deal with abuse was the van Binsbergen case. ${ }^{11}$ The case involved a legal representative, representing clients before certain administrative tribunals and courts in the Netherlands, where representation by a qualified lawyer, as a member of the bar, was not necessary. During the course of a particular proceeding the legal representative, $\mathrm{Mr}$ van Binsbergen, had transferred his residence from the Netherlands to Belgium. As a result, his capacity to represent his client before the Netherlands tribunal (Board of the Trade Association of the Engineering Industry) was challenged, on the legal basis that, under domestic law, residence in the Netherlands was a

Council Directive 2014/107/EU of 9 December 2014 amending Directive 2011/16/EU as regards mandatory automatic exchange of information in the field of taxation [2014] OJ L359/1; Council Directive (EU) 2015/121 of 27 January 2015 amending Directive 2011/96/EU on the common system of taxation applicable in the case of parent companies and subsidiaries of different Member States [2015] OJ L21/1; Council Directive (EU) 2015/2376 of 8 December 2015 amending Directive 2011/16/EU as regards mandatory automatic exchange of information in the field of taxation [2015] L332/1; Council Directive (EU) 2016/881 of 25 May 2016 amending Directive 2011/16/EU as regards mandatory automatic exchange of information in the field of taxation [2016] OJ L146/8; Council Directive (EU) 2016/1164 of 12 July 2016 laying down rules against tax avoidance practices that directly affect the functioning of the internal market [2016] OJ L193/1 ('ATAD 1'), as subsequently amended by Council Directive (EU) 2017/952 of 29 May 2017 amending Directive (EU) 2016/1164 as regards hybrid mismatches with third countries [2017] OJ L144/1 ('ATAD 2'; collectively, ATAD 1 and ATAD 2 are 'ATAD').

11 Case 33/74 Van Binsbergen v Bedriffsereniging voor de Metaalnijverheid (1974) ECLI:EU:C:1974:131. 
condition to act as a legal representative for clients and that condition was no longer fulfilled. The representative defended himself by appealing to the freedom to provide services under the then articles 59 and 60 TEC. The CJEU held that:

Likewise, a Member State cannot be denied the right to take measures to prevent the exercise by a person providing services, whose activity is entirely or principally directed towards its territory, of the freedom by article 59 for the purpose of avoiding the professional rules of conduct which would be applicable to him if he were established within that state; such a situation may be subject to judicial control under the provision of the chapter relating to the right of establishment and not of that on the provision of services. ${ }^{12}$

That is, this question was not controlled by the freedom to provide services, but by the question whether the right of establishment had been violated.

The CJEU explained that:

In accordance with these principles, the requirement that persons whose functions are to assist the administration of justice must be permanently established for professional purposes within the jurisdiction of certain courts and tribunals cannot be considered incompatible with the provisions of articles 59 and 60 (freedom to provide services), where such requirement is objectively justified by the need to ensure the observance of professional rules of conduct connected, in particular, with the administration of justice and with respect for professional ethics. ${ }^{13}$

That is, a condition imposing residence to carry on legal representation before a tribunal was justified, when the purpose was the control and application of professional rules of conduct connected with the exercise of the legal representation. However the CJEU made an important caveat under the right of establishment:

That cannot, however, be the case when the provision of certain services in a Member State is not subject to any sort of qualification or professional regulation and when the requirement of habitual residence is not subject to any sort of qualification or professional regulation and when the requirement of habitual residence is fixed by reference to the territory of the State in question. ${ }^{14}$

The CJEU concluded: 'that the national law of a Member State cannot, by imposing a requirement as to habitual residence within that state, deny 
persons established in another Member State the right to provide services, where the provision of services is not subject to any special condition under the national law applicable.' ${ }^{15}$ That is, the decision of the CJEU was clear. The fundamental freedoms protecting non-nationals and non-residents who are economically active in a Member State do not constitute a legal ground to escape specific professional rules prevailing in the Member State in which they are active and a territorial residence requirement connected to the effective observance of these rules is a valid exception to the non-discrimination rule for non-nationals and non-residents. However, a single residence requirement that is not connected to such professional rules is a prohibited discrimination, under the right of establishment.

1.9 That decision was clarified a few years later in a case ${ }^{16}$ in which a Dutch national, who had been active as a plumber in Belgium for many years, applied for an authorisation to exercise his trade in his country of origin, the Netherlands. The application was refused on the legal ground that the applicant did not meet the professional qualifications for plumbers in the Netherlands. In Belgium apparently there were no special professional requirements for exercising the trade of plumber. However there was a directive No. 64/427/EEC on transitional measures, providing in Article 3 that when in a Member State, the taking up or pursuit of any activity referred to in the directive is dependent on the possession of certain qualifications: 'That Member State shall accept as sufficient evidence of such knowledge and ability the fact that the activity in question has been pursued in another Member State'. The Netherlands government argued abuse of Community law: 'The Netherlands government draws attention to the risk that nationals of a Member State might evade the application of their national provisions in the matter of training for a trade if they were authorised to avail themselves, as against their own national authorities, of the facilities created by the directive'. ${ }^{17}$ The CJEU clearly leaned towards the protection of the fundamental economic rights by holding:

In this case, however, it should be borne in mind that, having regard to the nature of the trade in question, the precise conditions set out in article 3 of Directive No. 64/427, as regards the length of periods during which the activity in question must have been pursued, have the effect of excluding ... the risk of abuse referred to by the Netherlands government. ${ }^{18}$ 
Van Binsbergen and Knoors are two cases that can be categorised as 'abusive rule avoidance', avoiding cumbersome rules in the exercise of an economic activity. Other cases are better categorised as 'abusive benefit appropriation'. These are cases in which a person tries to bring himself within the scope of an EU treaty rule or directive providing for a benefit. An early case of this type was Cremer on the grant of an export refund for specific categories of animal feed compounds. ${ }^{19}$ The export refund was dependent on the composition of the product and regulated by various EU regulations. By adding an insignificant amount of a certain ingredient, the exporter of the product claimed an export refund for the whole product. After a quite complicated analysis the CJEU concluded that the export refund could only be granted provided that the product contained the required ingredients in proportions that were meaningful in reflecting price differentials. ${ }^{20}$ Although the decision referred to 'abusive practices by an exporter'21 it did not refer to any doctrine of abuse of Community law. But the facts in this case which involved the export of products with a heavy starch content closely resemble another famous case of the export of starch, a quarter of a century later, which would open the way for the doctrine of abuse of Community law in taxation. ${ }^{22}$

\section{TAX AVOIDANCE AS A JUSTIFICATION FOR MEASURES RESTRICTING THE FUNDAMENTAL FREEDOMS}

\section{Extending justifications to 'fiscal supervision' under the Rule of Reason}

The reason why national tax administrations were invoking tax evasion and tax avoidance as legal grounds for restricting the fundamental freedoms of taxpayers had its origin in the famous case of Cassis de Dijon which was a non-tax case, in which the CJEU, obiter dictum, made a reference to 'fiscal supervision'.23 In that case the CJEU was confronted with a nondiscriminatory rule prohibiting the marketing in Germany as liquor, alcoholic drinks with an alcoholic content below a certain minimum (25\%). The rule applied in general to all alcoholic drinks in Germany regardless of whether

19 C-125/76 Cremer v BALM (1977) ECLI:EU:C:1977:148.

20 Ibid. para. 13 ('It appears clearly from [the first recital in the preamble to Regulation 171/64 on animal feed-compounds] that the objective of the refund on exports to third countries is to compensate for the effect on the prices of the compound feeding-stuffs of the rules applicable to the ingredient used') and para. 14 ('It appears in any event clear that a compound feeding-stuff which contains only one product coming under Regulation 19 and that in insignificant proportions cannot give rise to a claim for a refund').

21 Ibid. para. 21.

22 Case C-110/99 Emsland Stärke (2000) ECLI:EU:C:2000:695.

23 Cassis de Dijon, para. 8. 
they were produced locally or imported. The result was that a famous French liquor, named Cassis de Dijon, with less alcohol content, was excluded from the German market. The question raised before the CJEU was whether this rule was a measure having the equivalent effect of a quantitative restriction on imports prohibited under Article 30 of the EEC treaty. Unlike customs duties and quantitative restrictions on imports this rule restricting trade in alcoholic drinks was not exclusively targeted at the imports of goods, but also applied to domestic products produced locally.

1.12 The problem was that a few years earlier in a sweeping statement the CJEU had held that: 'All trading rules enacted by Member States which are capable of hindering, directly or indirectly, actually or potentially, intra-community trade are to be considered as measures having an effect equivalent to quantitative restrictions'. ${ }^{24}$ There was no doubt that the minimum alcohol requirement, although being non-discriminatory, had a restrictive effect on domestic, but also on cross-border, trade. The Court resolved this issue by looking for grounds for justifying the restriction. Oddly enough, the minimum alcohol requirement was justified by the German government by reasons of public health, which is explicitly mentioned in the EEC treaty as a justification for restricting intra-community trade. Instead of limiting itself to the justification of public health provided for in the EEC Treaty, the Court made another sweeping statement deciding:

Obstacles to movement within the Community resulting from disparities between the national laws relating to marketing of the products in question must be accepted in so far those provisions may be recognized as being necessary in order to satisfy mandatory requirements relating in particular to the effectiveness of fiscal supervision, the protection of public health, the fairness of commercial transactions and the defence of the consumer. ${ }^{25}$

1.13 By that statement the CJEU added three grounds for justification of restrictive measures that were not in the treaty: fiscal supervision, fairness of commercial transactions and defence of the consumer. By the same token the CJEU arrogated itself the power to act as the sole arbiter for accepting grounds for the justification of restrictive measures by the Member States, limiting the fundamental freedoms. In later cases the CJEU would extend considerably this discretionary power to accept justifications for restricting the freedoms that were not to be found in the text of the TFEU under the doctrine of the 'Rule of Reason'. The justification on the basis of 'fiscal supervision' opened 
the way for national tax administrations of the Member States to use tax avoidance and tax evasion as legal grounds to defend restrictive national tax measures.

\section{Initial rejection by the CJEU of tax avoidance as justification}

As soon as the European Court of Justice ventured into the area of income tax, avoidance and evasion have been used as a legal ground for the Member States to restrict the fundamental freedoms of taxpayers in cross-border transactions and arrangements. In the very first case of Avoir Fiscal the French tax administration already justified the denial of a tax credit - called the avoir fiscal - for dividend payments on shares held by permanent establishments (PEs) of non-resident companies with the argument that there was a risk of tax avoidance. The Court rejected that argument in the strongest terms: 'Furthermore, the risk of tax avoidance cannot be relied upon in this context. Article 52 of the EEC treaty does not permit any derogation from the fundamental principle of freedom of establishment on such a ground'. ${ }^{26}$

Because there was no EU concept of tax avoidance, national tax administrations could only base their argumentation on national concepts of tax avoidance. These national concepts of avoidance of national tax law were rejected as justification by the CJEU, because they were considered as being too general and too wide in scope thereby undermining the effective exercise of the fundamental freedoms in cross-border transactions. The CJEU restated this clearly in ICI more than a decade later than Avoir Fiscal:

As regards the justification based on the risk of tax avoidance, suffice it to note that the legislation at issue in the main proceedings does not have the specific purpose of preventing wholly artificial arrangements, set up to circumvent United Kingdom tax legislation, from attracting tax benefits, but applies generally to all situations in which the majority of a group of subsidiaries are established, for whatever reason, outside the United Kingdom. However the establishment of a company outside the United Kingdom does not, in itself necessarily entail tax avoidance, since that company will in any event be subject to the tax legislation of the State of establishment. ${ }^{27}$

The CJEU was unwilling to equate establishments or activities outside the national tax jurisdiction with tax avoidance, as was often the case in national

26 Case 270/83 Commission v France (1986) ECLI:EU:C:1986:37 (hereafter 'Avoir Fiscal') para. 25.

27 Case C-264/96 Imperial Chemical Industries v Colmer (1998) ECLI:EU:C:1998:370 (hereafter 'ICI') para. 26. 
anti-avoidance rules, in particular when there was a reasonable business explanation for the cross-border move. ${ }^{28}$

\section{Marks \& Spencer, the turning point}

1.16 The turning point with respect to tax avoidance as a justification for restrictive measures came in 2005 with the decision in Marks E Spencer in which the CJEU accepted tax avoidance. The specific risk accepted by the Court was described as follows:

As regards ... the third justification, relating to the risk of tax avoidance, it must be accepted that the possibility of transferring losses incurred by a non-resident company to a resident company entails the risk that within a group of companies losses will be transferred to companies established in Member States which apply the highest rates of taxation and in which the tax value of the losses is therefore the highest. ${ }^{29}$

1.17 It should be noted that the specific argument about companies transferring their losses from Member States with low corporate income tax rates to Member States with high corporate tax rates to save taxes, was certainly not applicable in the case of Marks E Spencer, because at the time the companies with losses in Belgium and France were subject to a substantially higher tax rate than companies in the UK. ${ }^{30}$

1.18 Together with the double use of losses and the balanced allocation of taxing power the CJEU accepted tax avoidance as a kind of 'multiple justification' for restricting the cross-border carry-over of losses within an international group of companies:

In the light of those three justifications, taken together, it must be observed that restrictive provisions such as those at issue in the main proceedings pursue legitimate objectives which are compatible with the Treaty and constitute overriding reasons in the public interest and that they are apt to ensure the attainment of those objectives. ${ }^{31}$

1.19 However, the breakthrough of tax avoidance as a justification for a restriction of the fundamental freedoms did not mean that any concept of tax avoidance submitted by a national tax administration had become acceptable to the

28 Joined Cases C-397/98 and C-410/98 Metallgesellschaft and Others (2001) ECLI:EU:C:2001:134 para. 57; Case C-324/00 Lankhorst-Hohorst (2002) ECLI:EU:C:2002:749 para. 37; Case C-9/02 de Lasteyrie du Saillant (2004) ECLI:EU:C:2004:138 para. 50.

29 Case C-446/03 Marks \& Spencer (2005) ECLI:EU:C:2005:763 para. 49.

30 The UK budget of 1999 fixed the statutory corporate income tax rate at 30\%. In Belgium at the time it was $40.17 \%$.

31 Case C-446/03 Marks \& Spencer para. 51. 
CJEU. It was only when in a specific case tax avoidance could be framed as a case of abuse of Community law under the fundamental freedoms, that the CJEU would be willing to apply national tax rules specifically targeting such abuses.

\section{TAX AVOIDANCE AS ABUSE OF COMMUNITY LAW}

\section{Abuse of Community law in customs}

The first area of tax law where the doctrine of abuse of Community law was applied successfully was in the area of customs. ${ }^{32}$ The case concerned the export of agricultural products from Germany to Switzerland, which was subject to an export refund under EC rules. Immediately after arrival, when the goods were released from customs in Switzerland, they were re-imported in Germany and Italy by the same means of transportation, without being altered and even without being unloaded. Prior to re-importation however the goods were sold by the importer to an associated company in Switzerland so that the re-importation in the EU was formally effectuated by a different entity. Because the amount of the refund upon exportation exceeded the amount of import duties due upon re-importation the trade was profitable. The German customs authorities claimed back the export refund.

The Commission argued that the trader had committed an abuse of right under Community law:

By virtue of the legal principle of abuse of right in force of Community law financial advantages are not to be granted, if it is shown that the commercial operations at issue were for the purpose of obtaining an advantage which is incompatible with the objectives of the applicable Community rule in that the conditions for obtaining that advantage were created artificially. ${ }^{33}$

The CJEU followed the reasoning of the Commission: 'In that regard it is clear from the case law of the Court that the scope of Community regulations must in no case be extended to cover abuses on the part of the trader' and held that the abuse consisted of two elements: one objective element being 'a combination of objective circumstances in which despite of the formal observance of the conditions laid down by the (EU) rules, the purpose of those rules has not been achieved' and a subjective element being 'the intention to obtain 
an advantage form the (EU) rules by creating artificially the conditions laid down for obtaining it'. ${ }^{34}$ The CJEU concluded: 'It is for the national court to establish the existence of those two elements, evidence must be adduced in accordance with the rules of national law, provided that the effectiveness of Community law is not thereby undermined'. ${ }^{35}$ Emsland Stärke was the seminal decision to the two leading decisions, a few years later, defining the abuse of Community law in VAT and in corporate income tax.

\section{Halifax: abuse of law is an interpretation principle of EU law}

1.22 In Halifax, ${ }^{36}$ the CJEU was confronted with the question whether there was a legal ground for a national tax administration to deny a taxpayer a deduction for input VAT, on the basis of 'abuse', while in the text of the sixth VAT directive there was no reference to any concept of abuse. The advocategeneral, Poiares Maduro, argued in his opinion: '... this notion of abuse operates as a principle governing the interpretation of Community law ${ }^{37}$ and therefore the principle of 'abuse of Community law' could be applied in VAT as part of Community law, even though the directive did not contain any reference to that principle. The CJEU went along with this argument and, by and large, confirmed the concept of abuse of Community law as it had been elaborated in Emsland Stärke for the application of EU customs law:

For it to be found that an abusive practice exists, it is necessary, first, that the transactions concerned, notwithstanding formal application of the conditions laid down by the relevant provisions of the 6th Directive and the national provisions transposing it result in the accrual of a tax advantage the grant of which would be contrary to the purpose of the provision [and s] econd it must be apparent from a number of objective factors that the essential aim is to attain a tax advantage. ${ }^{38}$

Halifax established the principle that abuse of Community law is an overriding principle of interpretation of any form of Community law and that this principle must be applied, even when there is no clear reference to that principle in the EU rules or regulations that are to be applied. In Halifax the rule to be applied was secondary EU tax law, not containing any anti-abuse rule. The concept of what constituted abuse was derived from the concept of 'abuse of Community law', which had been applied in all kinds of other areas of law, except for tax law.

34 Ibid. paras 51-53.

35 Ibid. para. 54.

36 Case C-255/02 Halifax and Others.

37 Ibid. para. 69.

38 Ibid. para. 86. 


\section{Cadbury Schweppes: limiting tax avoidance to abuse of Community law}

It is generally accepted that the notion of abuse elaborated in Halifax has been refined and applied to corporate income tax in the Cadbury Schweppes decision. But, apart from the question of what is tax avoidance in national tax law, the nature of the question in Cadbury Scbweppes was totally different. In Cadbury Schweppes there was an existing national anti-abuse provision available and the question was whether this provision of national law was compatible with the freedom of establishment, which is not a rule of secondary EU law but a TFEU rule. In Halifax there was no built in conflict between the EU VAT rule and the concept of abuse of Community law. It was a conflict similar to a conflict under national tax law between a taxpayer and the tax inspector about the correct interpretation and application of this concept to the VAT rule allowing a credit for input tax. In Cadbury Schweppes there was a conflict not only between a taxpayer and the national tax inspector, but also between two different legal orders: the EU treaty with the objective of freedom of crossborder establishment and the national tax law with the objective of protection of the national tax base against cross-border low tax competition in other Member States. That is, from an EU legal point of view the question in Cadbury Schweppes should be considered not so much as a question of national tax avoidance, but rather as a question of the correct application of the freedom of establishment under the TFEU. That is a different question from the question of tax avoidance under national tax law. Therefore the decision in Cadbury Schweppes must be read for what it is: a decision on abuse of Community law and not so much a decision on tax avoidance. It is a decision limiting the scope of a national rule against tax avoidance as a justification for measures restricting the fundamental freedoms under the TFEU. Therefore also Cadbury Schweppes and other decisions on abuse of Community law cannot be compared to national court decisions on tax avoidance. The decisions on abuse of tax cases of the CJEU should not be compared to national court decisions on tax avoidance under national tax law, but rather to other decisions of the CJEU on abuse of Community law in other areas of law such as trade practices, family law etc. From this perspective it is easier to understand the true meaning of Cadbury Schweppes.

In Cadbury Schweppes, ${ }^{39}$ the CJEU had to deal with a classical CFC antiavoidance rule targeting passive income of a wholly owned subsidiary subject to a low tax rate as an International Financial Services Company in Dublin, Ireland. Immediate taxation on behalf of the UK parent company could only 
be avoided, when a few safe haven rules were met, or failing these safe haven conditions, when a motive test was met. The problem was with the motive test which provided two cumulative conditions: (1) where the transaction which gave rise to the $\mathrm{CFC}$ profits exceeded a minimum reduction in UK tax, compared to the tax which would have been payable in the absence of the transaction, the resident company had to show that the tax reduction was not the main purpose or one of the main purposes of the transaction, and (2) the resident company had to show that tax reduction was not the main reason, or one of the main reasons for the diversion of profits by setting up the foreign $\mathrm{CFC}$ and that in the absence of the $\mathrm{CFC}$ it was reasonable to suppose that the profits would have been taxable in the hands of the UK resident company.

1.25 Two considerations are essential in the Cadbury Schweppes decision. The first one is:

... the fact that a Community national whether a natural or a legal person sought to profit from tax advantages in force in a Member State other than his State of residence cannot deprive him of the right to rely on the provisions of the Treaty ... As to the freedom of establishment, the Court has already held that the fact that a company was established in a Member State for the purpose of benefiting from a more favourable tax legislation does not in itself suffice to constitute abuse of that freedom. ${ }^{40}$

That means that the fact that a taxpayer moves to another Member State or engages in a cross-border transaction with the avowed purpose of paying less taxes cannot in itself establish abuse, on the condition that the move is genuine. That is, the subjective intention to benefit from a tax advantage is irrelevant, if the exercise of the fundamental freedom is effective and genuine.

1.26 The second one deals with the appreciation of the non-genuine character of the cross-border move. The threshold which the CJEU has determined in a long line of cases for the non-genuine exercise of the fundamental freedoms is quite clear: only a 'wholly artificial arrangement' 41 falls short of the implementation of the treaty freedoms. Only anti-tax avoidance rules that specifically target such 'wholly artificial arrangements' are acceptable as a restriction of the fundamental freedoms: 'the specific objection of such a restriction must be to prevent conduct involving the creation of wholly artificial arrangements which

40 Ibid. paras 36-37, with references to Case C-212/97 Centros ECLI:EU:C:1999:126 para. 18 and Case C-167/01 Inspire Art ECLI:EU:C:2003:512 para. 96.

41 See Case C-264/96 ICI; Joined Cases C-397/98 and C-410/98 Metallgesellschaft and Others; and Case C-324/00 Lankhorst-Hohorst. 
do not reflect economic reality'. ${ }^{42}$ The Court further defines such wholly artificial arrangement at the end of its decision:

in order to find that there is such an arrangement there must be, in addition to a subjective element consisting of the intention to obtain a tax advantage, objective circumstances showing that, despite the formal observance of the conditions laid down by Community law, the objective pursued by the freedom of establishment has not been achieved. ${ }^{43}$

And 'that finding must be based on objective factors which are ascertainable by third parties with regard, in particular, to the extent to which the CFC physically exists in terms of premises, staff and equipment'. ${ }^{44}$

For national tax inspectors and also for quite a few tax professionals the criterion of 'wholly artificial arrangement' may sound much too formalistic an approach to be successful in the fight against tax avoidance. However, we should not forget that the CJEU is not deciding issues of tax avoidance, but only questions regarding the abuse of treaty freedoms and the protection of those freedoms against barriers put up by national tax rules, the only justification of which is the violation of those freedoms. We all know how wide tax administrations within a purely national context tend to cast the net of tax avoidance. Within this national context Member States still have absolute sovereignty to determine in their statutory rules how they want to tax. Within the European context that power is limited however by the fundamental freedoms and the CJEU, as the sole judge to determine the limits of those freedoms, has determined those limits as 'wholly artificial arrangements' which should be tested on objective facts ascertainable by third parties.

In judging the artificiality of an arrangement under the fundamental freedoms the CJEU clearly has a different view from that of tax administrations on the artificiality of an arrangement under the national tax law. The difference in the concept of avoidance between the CJEU and national tax administrations lies in the difference of the degree of 'commensurateness' between the importance of an economic activity and the amount of taxable profits generated by such an activity. The CJEU accepts a minimal 'threshold' of effective activity as sufficient evidence for the exercise of the freedoms, regardless the amount of taxable income that corresponds to that activity. Tax administrations tend to

42 Case C-196/04, Cadbury Schweppes para. 55.

43 Ibid. para. 64.

44 Ibid. paras 64 and 67. 
reject an activity as an artificial arrangement when the amount of taxable profits is to a certain degree not commensurate with the low volume of that activity.

\section{Variations in the wording of CJEU case law after Cadbury Schweppes}

1.29 Although the standards for accepting a restrictive national tax measure against abuse of Community law were clearly set by the CJEU in Cadbury Schreppes, the Court has not always been consistent in the wording used in subsequent case law. In Thin Cap GLO, the CJEU confirmed that restrictive measures are only acceptable:

unless first, that legislation provides for objective and verifiable elements which make it possible to identify the existence of a purely artificial arrangement, entered into for tax reasons alone and allows taxpayers to produce ... without being subject to undue administrative constraints, evidence as to the commercial justification for the transaction. ${ }^{45}$

1.30 In Part Service, which was a case on VAT and not on the Treaty freedoms, the referring Court, pointing to the Halifax decision, put the precise question whether:

the Sixth Directive should be interpreted as meaning that there can be a finding of an abusive practice when the accrual of a tax advantage is the principal aim of the transaction ..., or of such finding can only be made if the accrual of that tax advantage constitutes the sole aim pursued, to the exclusion of other economic objectives. ${ }^{46}$

1.31 The CJEU answered that the statement about 'the sole aim' in Halifax was a finding of fact and not a statement of law:

... when it (the CJEU) stated, in ... that judgement, that in any event, the transaction at issue had the sole purpose of obtaining a tax advantage, it was not establishing that circumstance as a condition for the existence of an abusive practice, but simply pointing out that, in the matter before the referring court in that case, the minimum threshold for classifying a practice as abusive had been passed ...

And concluded that " $t]$ he reply to the first question therefore is that the Sixth Directive must be interpreted as meaning there can be a finding of an abusive 
practice when the accrual of a tax advantage constitutes the principal aim of the transaction ...' 47

That holding was confirmed more recently, when the CJEU held: '... The case law stemming from the judgement in Halifax does not require it to be established that the accrual of a tax advantage is the only objective of the transaction at issue'. ${ }^{48}$ In holding so, the CJEU gave more room for manoeuvre to tax administrations to apply the abuse principle in VAT, because next to the essential tax purposes the taxpayer could also harbour some non-essential business purposes. This case law does not invalidate Cadbury Schweppes, because the essence of that decision is that when a taxpayer effectively exercises his fundamental freedoms that non-tax purpose is so essential that it invalidates the justification of tax avoidance.

In a number of cases, including the Danish Beneficial Ownership Cases, ${ }^{49}$ the CJEU has stated that tax avoidance was a sufficient justification for denying tax advantages when it was 'the principal or one of the principal objectives of an arrangement'. ${ }^{50}$ However all these cases relate to various texts of secondary EU law, the merger directive, the parent-subsidiary directive, the interest royalty directive, which apply national anti-avoidance rules or anti-avoidance rules in secondary EU law that literally refer to tax evasion or tax avoidance as one of 'the principal or one of the principal objectives' of a transaction. Because these decisions only relate to national law or secondary EU law, they cannot be used as authority that tax avoidance should be accepted as a justification for setting aside the effect of one of the fundamental freedoms under the TFEU, when it is the principal or one of the principal objectives of a tax arrangement. But it is clear that in the last CJEU decisions of the Danish Beneficial Ownership Cases, we are getting to the point where the formulation of BEPS rules in OECD documents is practically the legal basis for the interpretation of EU directives. In its final holding the CJEU takes the position that "when there is fraud or abuse ... application of the freedoms enshrined in the FEU Treaty cannot be relied on in order to call into question the legislation of the ... Member State governing the taxation of that interest'. ${ }^{51}$ Prima facie that holding seems to overrule Cadbury Schweppes,

47 Ibid. paras 44 and 45.

48 Case C-251/16 Cussens and Others (2017) ECLI:EU:C:2017:881 para. 53.

49 Joined Cases C-115/16, C-118/16, C-119/16, and C-299/16 N Luxembourg 1 ECLI:EU:C:2019:134 (hereinafter: ' $N$ Luxembourg 1') and Joined Cases C-116/16 and C-117/16 T Danmark ECLI:EU: C:2019:135 (hereinafter: 'T Danmark') are collectively referred to as the 'Danish Beneficial Ownership Cases').

50 Case C-321/05 Kofoed (2007) ECLI:EU:C:2007:408 para. 38; Case C-126/10 Foggia SGPS (2011) ECLI: EU:C:2011:718 para. 50; T Danmark, para. 100; N Luxembourg 1, para. 127.

$51 N$ Luxembourg 1, para. 180. 
which had held that a restriction of the fundamental freedoms based on tax avoidance or abuse was always subject to scrutiny of the CJEU. Therefore the decision has already been criticised $^{52}$ in the literature. However this question has been raised after this chapter had been finished and for that reason is not dealt with here. The case has not yet been finally decided and very probably will be the object of another procedure before the CJEU.

\section{E. TRADITIONAL FORMULATION OF ANTI-AVOIDANCE RULES IN EU DIRECTIVES}

\section{Two formulas of traditional formulation of anti-avoidance rules}

1.34 The traditional way of formulating anti-tax avoidance rules is to be found in the dividend and merger directives of 1990 and the interest royalty directive of 2003. ${ }^{53}$ Those directives contain two different categories of anti-avoidance rules: (1) one rule referring to national domestic or agreement-based antiavoidance rules and (2) one rule denying the tax benefit of a directive, when the principal or one of the principal motives of a transaction is tax evasion or tax avoidance. The merger directive contains the specification that 'the fact that one of the operations ... is not carried out for valid commercial reasons ... may constitute a presumption that the operation has tax evasion or tax avoidance $\ldots$ as one of its principal objectives'.

\section{The reference to national and agreement-based rules}

1.35 First these rules confirm that agreement or domestic-based national antiavoidance rules remain applicable, subject of course to the pre-eminence of the fundamental freedoms in the TFEU. That pre-eminence was confirmed in Bosal, when the CJEU stated that the refusal in national tax law of an interest deduction on a loan to finance a share acquisition, was to be applied in a non-discriminatory way to domestic and cross-border acquisitions in accordance with the freedom of establishment. ${ }^{54}$ As to the question which

52 W.Schön, The Concept of Abuse of Law in European Taxation: A Methodological and Constitutional Perspective, Max Planck Institute for Tax law and Public Finance, Working paper 2019-18 (Nob. 2019); L. De Broe and S. Gommers, Danish Dynamite: The 26 February 2019 CJEU Judgements in the Danish Beneficial Ownership Cases, 2019 (6) EC Tax Review, 270 - 299; F. Vanistendael, Tax Abuse in Europe: The CJEU's N Luxembourg 1 and T Danmark Judgments, 97 Tax Notes Int'1 629, no. 6.

53 Council Directive 90/435/EEC (repealed), supra n. 4, Article 1(2); Council Directive 90/434/EEC (repealed), supra n. 5, Article 11; and Council Directive 2003/49/EC of 3 June 2003 on a common system of taxation applicable to interest and royalty payments made between associated companies of different Member States [2003] OJ L157/49, Article 5.

54 Case C-168/01 Bosal (2003) ECLI:EU:C:2003:479 paras 26 and 27. 
national anti-avoidance rules would be acceptable under the fundamental freedoms, the CJEU held early on that only national rules targeting 'wholly artificial arrangements' in the exercise of the fundamental freedoms would be acceptable..$^{55}$

More recently the CJEU has reiterated the priority of the fundamental freedoms over national anti-avoidance provisions in the parent subsidiary directive. ${ }^{56}$ The argument of the tax administration was that any national measure which has been subject to exhaustive harmonisation at the level of the European Union must be assessed in the light of the provisions of that harmonising measure, without taking into account the provisions of the fundamental freedoms under the TFEU. In case of exhaustive harmonisation, secondary law like directives has priority to primary law. ${ }^{57}$ Whether a French national anti-tax avoidance rule was a valid domestic rule under Article 1(2) of the parent subsidiary directive depended on whether that directive constituted a measure of complete harmonisation of income taxation of cross-border dividends. The CJEU held that that was obviously not the case and therefore the national anti-avoidance rule had to be tested under the freedom of establishment. The French anti-avoidance rule contravened against the condition of a 'wholly artificial arrangement' and therefore was not applicable.

\section{The reference to 'the principal objective or one of the principal objectives'}

The second rule denies the benefit of the directive, when tax avoidance is 'the principal motive or one of the principal motives' of the transaction or arrangement. That formulation in the merger and the interest-royalty directive seems in a certain way to anticipate the current formulation of PPT, but historically there has been no such link. At the time there was no PPT standard at the international level and general GAAR tests in national legislation were concentrating on the question of whether tax avoidance was the 'sole, the decisive, the dominant reason', or in in its weakest form the 'main reason' of the transaction or arrangement. ${ }^{58}$

55 Case C-264/96 ICI para. 26.

56 Case C-6/16 Eqiom and Enka (2017) ECLI:EU:C:2017:641.

57 Ibid. para. 15; see also, in an area outside taxation, C-198/14 Visnapuu (2014) ECLI:EU:C:2015:751 para. 40.

58 See the collective comparative survey found in G.S. Cooper, Tax Avoidance and the Rule of Law (IBFD Publications/Australian Tax Research Foundation, 1997) 378 et seq. 
1.38 The interpretation of that particular type of tax avoidance rule started in the Leur-Bloem decision. ${ }^{59}$ In that case the particular question was whether an exchange of the shares of two companies, wholly owned by the same shareholder, against the shares of a newly established holding company, in order to bring about a horizontal setting-off of tax losses within a consolidation framework between the three participating companies, was a valid commercial reason for the exchange transaction. Since this was the first decision on mergers, the CJEU did not answer all questions. It decided that the exchange of shares under the particular circumstances did not prevent the operation to qualify as a merger by exchange of shares under the merger directive. However the CJEU did not clarify what was to be understood by valid commercial purpose. The Court only described the conditions which the tax administration must fulfil in order to be able to apply the anti-avoidance rule: (1) the tax authorities must carry out a detailed examination of the particular operation and cannot confine themselves to applying predetermined general criteria and (2) the examination must be open to judicial review. ${ }^{60}$

1.39 The next step in interpretation was made in Kofoed where the CJEU made the direct link between the anti-avoidance rule in Article 11(1)(a) of the merger directive and the Community principle that abuse of rights is prohibited. ${ }^{61}$ That link was clearly made with hindsight, because at the time of the approval of the merger directive with the anti-avoidance rule of 'the principal or one of the principal objectives', the discussion in the Court of Justice on abuse of right in the area of taxation was still more than ten years away. ${ }^{62}$ Therefore evidence for a historic link between 'the principal or one of the principal objectives' and the Community principle of abuse of Community law is far from evident.

1.40 A more nuanced interpretation of Article 11(1)(a) followed in Foggia where the Court stated: '... a merger operation based on several objectives, which may also include tax considerations, can constitute a valid commercial reason provided, however, that those considerations are not predominant in the context of the proposed transaction'. ${ }^{63}$ That is, the commercial reasons must be predominant in order to apply the merger directive, but then the CJEU went so far to state: '... a merger or acquisition carried out in the form of the acquisition of a company that does not carry on activity and that does not

59 Case C-28/95 Leur-Bloem v Inspecteur Belastingdienst/Ondernemingen, Amsterdam 2 (1997) ECLI:EU: C:1997:369 (hereafter 'Leur-Bloem').

60 Leur-Bloem paras 41 and 48.

61 Case C-321/05 Kofoed para. 38.

62 See Case C-110/99 Emsland Stärke and C-255/02 Halifax and Others.

63 Case C-126/10 Foggia para. 35. 
contribute assets to the acquiring company may, nevertheless, be considered by the latter to have been carried out for valid commercial reasons'. ${ }^{64}$ Any clarity in interpretation was again confused however at the end of the decision, where the CJEU referred to Kofoed and confirmed that Article 11(1)(a) reflects the principle of abuse of rights in EU law: 'The application of EU legislation may not be extended to cover abusive practices, that is to say, transactions carried out not in the content of normal commercial operations, but "solely" for the purpose of wrongfully obtaining advantages provided for by that law'. ${ }^{65}$ The problem with that same holding is that the criterion for refusing the tax benefit according to the wording of Article 11(1)(a) is not that obtaining the tax benefit be the 'sole' purpose of the arrangement; rather, it is sufficient that the tax benefit be 'one of the principal objectives' and that that objective may constitute a presumption of tax avoidance, when there is no valid commercial purpose for the arrangement. It should also be noted that all these merger cases have been argued on the basis of secondary EU law, and that the fundamental freedoms were not at stake.

That was the case however in Euro Park Service, ${ }^{66}$ in which the question was raised whether a French anti-avoidance rule was compatible with the freedom of establishment. The reasoning of the Court was almost identical as in the Eqiom ${ }^{67}$ case on the parent-subsidiary directive of the same year. The question was whether the anti-avoidance provision of the merger directive, as secondary law, could in itself provide a complete legal justification for the national anti-avoidance rule in French tax law. The Court held that this was only allowed for areas of tax law that were fully harmonised, which was not the case in the merger directive. ${ }^{68}$ Next the Court tested the French rule on the freedom of establishment and held that:

Article 49 TFEU and Article 11(1)(a) of Directive 90.434 must be interpreted as precluding ... national legislation ..., which in the case of a cross-border merger, makes the granting of the tax advantages applicable to such operation ... subject to a process of prior approval under which, in order to obtain that approval, the taxpayer must show that the operation concerned is justified for commercial reasons, that it does not have as its principal objective, or one of its principal objectives, tax evasion or tax avoidance, and that its terms make it possible for the capital gains deferred for tax purposes to be taxed in the future, whereas in the case of a national merger such deferral is granted without the taxpayer bring made subject to such a process. ${ }^{69}$

64 Ibid. para. 40.

65 Ibid. para. 50.

66 Case C-14/16 Euro Park Service (2017) ECLI:EU:C:2017:177.

67 Case C-6/16 Eqiom and Enka.

68 Case C-14/16 Euro Park Service paras 19-26.

69 Ibid. para. 70. 


\section{Conclusion on traditional anti-avoidance rules}

1.42 In view of the fact that the rules of corporate income tax are only very partially harmonised in the EU the conclusion on the interpretation of national anti-avoidance rules and $\mathrm{EU}$ anti-avoidance rules in secondary law is that they firmly remain within the grip of the fundamental freedoms in primary EU law and can only be set aside when taxpayers exercise these freedoms in the form of 'wholly artificial arrangements'.

\section{F. BEPS: THE DIFFERENCE BETWEEN BASE EROSION AND TAX AVOIDANCE}

\section{The key indicators of the new approach}

1.43 The literature on BEPS is limitless and this chapter is not the place to make a complete survey of that literature, because for the purposes of this chapter such a complete survey is not necessary. It will suffice to highlight a few key ideas of the BEPS action programme that was approved on 5 October 2015 by the OECD and the Multilateral Instrument that was opened for signature on 1 January 2017. The key ideas that contrast the BEPS approach against the classical approach against tax avoidance can be summarized as follows: (1) the second objective of tax conventions is not 'to create opportunities for nontaxation or reduced taxation through tax avoidance or tax evasion'; (2) the introduction of special anti-avoidance rules (SAARs) to prevent treaty shopping situations and the inclusion of a Limitation on Benefits (LOB) rule in the OECD Model and; (3) the inclusion of a general PPT to restrict treaty benefits in situations not covered by LOB provisions. ${ }^{70}$

\section{The new objective of tax conventions}

1.44 In 2014 the OECD Committee of Fiscal Affairs decided to amend the title of the OECD Model Convention and to include a preamble as a result of the work undertaken as part of the OECD/G20 Base Erosion and Profit Shifting project. As a result, 'Prevention of tax evasion and avoidance' was specifically included in the title of the 2017 OECD Model. The preamble was also amended including a specific reference to the effect that it was not intended for 'creating opportunities of non-taxation or reduced taxation through tax evasion or avoidance (including through treaty shopping arrangement aimed at obtaining reliefs provided in this Convention for the indirect benefits of 
third States)'. The 2017 Commentary makes clear what was the intention of these amendments: 'Since the title and preamble form part of the context of the Convention and constitute a general statement of the object and purpose of the Convention, they should play an important role in the interpretation of the provisions of the Convention'. ${ }^{71}$

It is clear that in the BEPS doctrine the objectives of avoidance of nontaxation and reduced taxation are situated at the same level as the avoidance of double taxation. However, most of the current rules in the 2017 OECD Model are focused on the reduction or even elimination of double taxation. There are very few rules on the elimination of non-taxation. The objective of the BEPS action programme is to change that situation by incorporating new rules that act as anti-avoidance rules, as witnessed by several proposals for amending the 2017 OECD Model such as: (1) the specific rules extending the notion of permanent establishment; (2) several specific amendments of the 2017 OECD Model and/or the OECD Commentary to eliminate 'an improper use' of tax treaties; and specifically (3) Article 7 of the MLI on prevention of treaty abuse and the new article 29 on the entitlement of benefits incorporating a new LOB rule in the 2017 OECD Model.

\section{New BEPS rules for treaty benefits}

There are two ways to qualify for treaty benefits. The first way is to fulfil the conditions of a 'qualified resident' which act as safe haven rules for treaty benefits. If a taxpayer does not meet these conditions, a contracting jurisdiction 'may, nevertheless, grant the benefits' upon request of the taxpayer, if the competent authority determines that granting the benefits is justified in light of the reasons such resident did not satisfy the requirements. ${ }^{72}$ That decision is a fully discretionary decision by the competent tax authority granting or denying the request, not subject to any judicial control and apparently without any motivation. In the similar provision of the MLI, the condition is formulated somewhat differently, in that the competent authority takes into account the object and purpose of the tax treaty and only if the resident taxpayer demonstrates that neither the establishment, acquisition or maintenance, nor the conduct of the operations has as one of its principal purposes the obtaining of the treaty benefits. But here also there is no

71 See Introduction, Paragraph 16.2 of OECD, OECD Model Tax Convention on Income and on Capital (Condensed Version) (OECD Publishing 2017) (hereafter '2017 OECD Model'). The 2017 OECD Model includes, among other things, an Introduction (pages 9 through 21) and article-specific commentaries, and for the purposes of this Chapter, said commentaries are collectively referred to as the '2017 OECD Model Commentary'.

72 Article 29(8)(c) 2017 OECD Model. 
requirement of motivation, or judicial control, meaning that administrations decide in full discretion.

1.47 The second way of limiting treaty benefits is by applying the PPT described in Article 29(9) of the 2017 OECD Model. That provision prohibits ${ }^{73}$ com- $^{-}$ petent authorities to grant treaty benefits in respect of an item of income or capital:

if it is reasonable to conclude, having regard to all facts and circumstances, that obtaining that benefit was one of the principal purposes of any arrangement or transaction that resulted directly or indirectly in that benefit, unless it is established that granting that benefit in these circumstances would be in accordance with the object and purpose of the relevant provisions of this Convention.

1.48 The difference between the qualified residence approach and the PPT approach is that except for a Mutual Agreement Procedure (MAP), the application of Article 29(9) practically always takes place in a litigation context under the control of the judiciary, while a request for the application of treaty benefits by a non-qualifying resident takes place mostly outside a litigation context. That is, judicial control is not automatic.

1.49 However, the most important characteristic of the BEPS approach in both ways is that even when there is a serious business reason for the transaction of arrangement, that reason cannot save the application of a treaty benefit, if obtaining the treaty benefit must be considered as an objective of almost equal importance. In the classical anti-avoidance approach a valid commercial reason on behalf of the taxpayer has always been accepted as a sufficient justification for the tax benefit to apply. Under the BEPS approach that is no longer the case for benefits in tax treaties. ${ }^{74}$

73 Article 29(9) 2017 OECD Model states: 'shall not be granted'.

74 That results very clearly from the explanation for the denial of treaty benefits in case of change of residence, in which denial of treaty benefits is permitted 'notwithstanding the fact that there may also be other principal purposes for changing residence, such as facilitating the sale of the property or the re-investment of the proceeds of the alienation'. 2017 OECD Model Commentary on Article 29, paragraph 180. 


\section{G. NEW TAX AVOIDANCE RULES IN EU DIRECTIVES}

\section{A conventional start before BEPS}

Before the start of BEPS, the European Commission came out with its own EU action plan to strengthen the fight against tax fraud and tax evasion. ${ }^{75}$ In 2012, before the initiation of the BEPS action plan, it issued a General Recommendation to harmonise all GAARs in the Member States. The GAAR in that recommendation was squarely in line with Cadbury Schweppes:

An artificial arrangement or an artificial series of arrangements which has been put into place for the essential purpose of avoiding taxation and leads to a tax benefit shall be ignored. A purpose is essential when other purposes attributable to the arrangement appear at most negligible, in view of all the circumstances. National authorities shall treat the arrangement for tax purposes by reference to their economic substance. ${ }^{76}$

\section{The impact of BEPS in the Parent-Subsidiary Directive}

Gradually however the BEPS recommendations took over. The first signal was Directive 2014/86 of 8 July 2014 amending Article 4(1)(a) of the recast Parent-Subsidiary Directive 2011/96/EU in the sense that Member States shall only refrain from taxing foreign source dividends: 'to the extent that such profits are not deductible by the subsidiary, and tax such profits to the extent that such profits are deductible by the subsidiary. ${ }^{77}$ That new rule followed the draft recommendations of the OECD BEPS Action Plan (not yet approved) on hybrid financial instruments and was intended to counter disparities in the tax laws between Member States by which profit distributions that were exempt from corporate income tax in the Member State of residence of the parent company, were characterised as a deductible interest charge in the Member State of source of the subsidiary. The new element was that the rule applied as an automatic SAAR, regardless of the valid commercial objectives of the arrangement.

The next step was the introduction in Article 1(2) of the same parentsubsidiary directive of an 'harmonised' anti-avoidance rule:

75 Communication of the Commission to the European Parliament and the Council, EU Action Plan to strengthen the fight against tax fraud and tax evasion, COM(2012) 722 final, 6 December 2012.

76 Commission Recommendation on aggressive tax planning, COM(2012) 8806 final, 6 December 2014, no 4.2, p. 4.

77 Council Directive 2014/86/EU of 8 July 2014 amending Directive 2011/96/EU on the common system of taxation applicable in the case of parent companies and subsidiaries of different Member States [2014] OJ L219/40. 
Member States shall not grant benefits of this Directive to an arrangement or a series of arrangements which, having been put into place for the main purpose or one of the main purposes of obtaining a tax advantage that defeats the object and purpose of this Directive, are not genuine having regard to all relevant facts and circumstances. ${ }^{78}$

That wording was almost identical to the wording of the PPT which, at that time, figured already in the draft Action Plan 6 of the BEPS project of the OECD. That wording did neither reflect the concept of 'essential purpose' of the Halifax decision, nor the concept of 'wholly artificial arrangement' of the Cadbury Schweppes decision.

1.53 However in Article 1(3) of the Directive an important additional condition was inserted for the effective realisation of 'one of the main purposes': 'For the purposes of paragraph 2, an arrangement or a series of arrangement shall be regarded as not genuine to the extent that they are not put into place for valid commercial reasons which reflect economic reality'. The wording of that paragraph is a carbon copy of the wording used in Cadbury Schweppes to determine under which circumstances anti-avoidance rules cannot be invoked against the exercise of the fundamental freedoms.

1.54 The new provisions did not replace the old anti-avoidance Article 1(2) of the Parent Subsidiary Directive. The old article referring to domestic and agreement-based provisions was maintained and just relocated to Article 1(4) of the directive.

1.55 This amendment of the parent-subsidiary directive in 2015 can be considered as a kind of dress rehearsal for $\mathrm{ATAD}^{79}$ one year later. The formulation of the general anti-avoidance rule intended as a general harmonisation of all anti-tax avoidance rules in the EU was almost identical and also incomplete, because all Member States were allowed to apply stricter national anti-avoidance rules.

\section{GAAR in ATAD}

1.56 The ATAD contains several anti-avoidance rules that follow the recommendations of the BEPS Action Plan, which corresponds to the explicit objective of the directive. ${ }^{80}$ Most of the ATAD provisions are framed as

Council Directive (EU) 2015/121 of 27 January 2015 amending Directive 2011/96/EU on the common system of taxation applicable in the case of parent companies and subsidiaries of different Member States [2015] L21/1, Article 1(2).

79 ATAD, supra n. 10.

80 ATAD 1 (Directive 1164/2016), Recital 1 states, in relevant part: 'The final reports on the 15 OECD Action Items against BEPS were released to the public on 5 October 2015. This output was welcomed by the 
specific anti-avoidance rules that apply automatically, regardless of the commercial reasons for the arrangement. Because they disregard valid commercial reasons in their application they may fail to justify restrictions in the exercise of the fundamental freedoms, because of a lack of proportionality. However to the extent that these restrictions are equally applicable to purely domestic tax situations, there is no discrimination and therefore there is no violation of the fundamental freedoms. The question is whether the $\mathrm{EU}$ has the competence when it is imposing tax measures that clearly constitute barriers to crossborder trade, to regulate at the same time extensively purely domestic tax situations, just to escape the accusation that the measures would discriminate cross-border transactions. However we will not deal with these specific anti-avoidance rules in ATAD and focus on Article 6, which is the core issue.

Article 6 ATAD contains a GAAR that is applicable to all taxpayers subject to corporate income tax in one or more Member States, including permanent establishments in one or more Member States of residents for tax purposes in a third country. That is, all entities subject to corporate income tax also at a purely national level are subject to the same general anti-avoidance rule. Individuals are excluded. It should be noted that the scope of corporate income tax is not the same in all EU Member States. On one hand in Belgium almost any entity in corporate form is subject to corporate income tax and therefore subject to the harmonised anti-avoidance rule, while on the other hand in Germany many quite large enterprises are not in the form of a corporation and not subject to corporate income tax. In general, opaque partnerships subject to corporate tax will be subject to the rule, while transparent partnerships of individuals are not subject to the rule. Hence the impact of the GAAR may be quite different between Member States.

Finally, Article 3 ATAD allows stricter domestic or agreement-based rules, but not like in the old Article 1(2) of the parent subsidiary directive to prevent tax fraud or tax evasion, but to protect the domestic corporate tax base. By introducing that amendment in the old rule, ATAD is extending considerably the scope of potential exceptions to the fundamental freedoms. So far so good for the argument supporting the issuing of ATAD on the legal basis of coordinating harmonisation.

Council in its conclusions of 8 December 2015. The Council conclusions stressed the need to find common, yet flexible, solutions at the EU level consistent with OECD BEPS conclusions. In addition, the conclusions supported an effective and swift coordinated implementation of the anti-BEPS measures at the EU level and considered that EU directives should be, where appropriate, the preferred vehicle for implementing OECD BEPS conclusions at the EU level'. 
1.59 The new GAAR is formulated in Article 6 ATAD. It consists of three parts:

(a) For the purpose of calculating the corporate tax liability, a Member State shall ignore an arrangement or a series of arrangements which, having been put into place for the main purposes or one of the main purposes of obtaining a tax advantage that defeats the object and purpose of the applicable tax law, are not genuine having regard to all relevant facts and circumstances. An arrangement may comprise more than one step or part.

(b) For the purposes of paragraph 1, an arrangement or a series thereof shall be regarded as non-genuine to the extent that they are not put into place for valid commercial reasons which reflect economic reality.

(c) Where arrangements or a series thereof are ignored in accordance with paragraph 1, the tax liability shall be calculated in accordance with national law.

\section{The interpretation of GAAR in ATAD}

1.60 Paragraph 11 of the preamble of ATAD contains a few hints as to the interpretation of the new GAAR. First the function of that GAAR is to tackle abusive tax practices that have not yet been dealt with through specifically targeted provisions, i.e. it has the function to fill in the gaps. That means that the use of SAAR is not exhaustive, because, when through the application of a SAAR the abuse cannot be eliminated, the GAAR still may be applied. Then follows an important sentence for interpretation: 'Within the Union GAAR's should be applied to arrangements that are not genuine'. According to the preamble that means that: '.. the taxpayer should have the right to choose the most tax efficient structure for its commercial affairs'. The concept of genuine economic activities is clarified in the last sentence of that paragraph of the preamble: 'When evaluating whether an arrangement should be regarded as non-genuine, it could be possible for a Member State to consider all valid economic reasons, including financial activities'. That is very important, because financial activities are sometimes considered not to be 'genuine economic activities' to the same degree as industrial or trading activities, because financial activities are often considered to be tainted with elements of tax avoidance or evasion. The GAAR must also be applied uniformly within the Union, in domestic situations and in relationships with third countries, so that there is no difference in the scope and results of application in domestic and cross-border situations. Finally, the preamble suggests that Member States can apply penalties in addition to the application of the EU GAAR. 
It is too early to envisage how this GAAR will be interpreted by the national courts of the Member States and above all by the CJEU. The way in which Article 6 ATAD has been implemented by the Member States opens the possibility of very divergent applications of the 'common' anti-avoidance rule. Not less than 19 of the $28 \mathrm{EU}$ Member States have indicated that they have already an anti-avoidance rule in force or national case law with an equivalent effect $^{81}$ and expect no significant changes in the application of anti-avoidance rules. If we compare just four Member States in the heart of the EU (Belgium, France, Germany and the Netherlands) we already see substantial differences in the way the national anti-avoidance rule is formulated. The Netherlands has no statutory anti-avoidance rule, but the GAAR concept of ATAD is said to be incorporated in the concept of 'fraus legis' which is used in case law in the Netherlands. In French tax law tax avoidance is linked to an 'exclusive purpose' which, prima facie, seems in contradiction with 'one of the main purposes' of the ATAD wording. Belgium has a detailed anti-avoidance rule, which emphasises the 'purpose' of the tax law. Germany has in its general tax law an anti-abuse provision that is applicable if an inappropriate legal structure is chosen, resulting in a tax advantage for which the taxpayer cannot provide sufficient non-tax reasons. All these differences do not matter that much for the interpretation of tax situations within a purely local context. But at this stage it is not clear how the CJEU will make all these national versions of the ATAD GAAR compatible in cross-border situations involving large parts of the EU with several different Member States, referring to differently worded anti-avoidance rules.

Limiting ourselves to the interpretation of the text of Article 6 ATAD we should first make a distinction to situations dealing only with national tax law or secondary EU law and those situations also raising the application of fundamental freedoms under the TFEU. From the latest cases in the application of anti-avoidance provisions in EU directives it is clear that as long as there is no exhaustive harmonisation of a tax law area by directive or regulation, the primacy of fundamental freedoms in the TFEU remains unchallenged. ${ }^{82}$ That means that regardless what the interpretation of Article 6 ATAD may be by a national court or the CJEU in secondary EU legislation, the restrictions of the fundamental freedoms resulting from these interpretations, in order to be accepted by the CJEU, must pass the muster of the 'wholly artificial arrangement' standard of Cadbury Schweppes; i.e. when the taxpayer genuinely effectuates his economic freedom, there can be no abuse of

81 EY European Anti-Tax Avoidance Directive - Implementation, Overview July 2018: Belgium, Bulgaria, Croatia, Cyprus, Estonia, Finland, France, Germany, Greece, Hungary, Italy, Malta, the Netherlands, Poland, Portugal, Slovenia, Spain, Sweden and the UK.

82 See Case C-6/16 Eqiom and Enka and Case C-14/16 Euro Park Service. 
the TFEU and therefore the effect of the TFEU has precedence and tax avoidance cannot be invoked as a justification for a discriminating restriction.

1.63 In situations where the fundamental freedoms are at stake, for instance because there is unequal treatment under a concrete rule of national tax law, between a cross-border and a purely national situation the interpretation of Article 6 ATAD does matter and the outcome of the interpretation is important. The fact that the EU GAAR is equally applicable to purely national tax situations is insufficient to eliminate the possibility of discrimination, because the concrete outcome of a rule of national tax law may be different for cross-border and purely domestic situations.

1.64 Prima facie one is of course struck by the similarity between the first part of Article 6 and the PPT rule in Article 29(9) of the 2017 OECD Model. Article 6 ATAD is almost the literal transcription of Article 29(9). Both 'one of the principal purposes' and the 'object and purpose' of the law figure in either text. That is in particular striking, because the draft proposal of less than six months earlier still contained the magic words 'essential purpose', which reflected the Halifax and therefore also the Cadbury Schweppes case law. ${ }^{83}$ Therefore the first reaction on this similarity is that Article 6 ATAD should be interpreted in the same way as a principal purpose test as it had been incorporated a few months earlier in BEPS action plan 6. However it is interesting to note that in another document from the same day, a Commission Recommendation on the implementation of measures against treaty abuse, there was an explicit reference to the PPT in the BEPS Action Plan literally referring to 'one of the principal purposes' as the decisive test, but at the same time referring to 'a genuine economic activity' like in the Cadbury Schweppes decision. ${ }^{84}$

1.65 These altered words are indeed the essential difference with BEPS. In the first and the final draft of ATAD non-genuine arrangements were defined in paragraph 2 of the article as carried out not for commercial reasons, which reflect economic reality. That means that the first paragraph does not apply to arrangements that are considered as 'genuine'. That specification is completely absent from the PPT in Article 29(9) of the 2017 OECD Model. Under BEPS the benefit can only be granted when it is established that taking into

83 See Proposal for a COUNCIL DIRECTIVE laying down rules against tax avoidance practices that directly affect the functioning of the internal market COM(2016) 26 final 2016/0011 (CNS). Proposed Article 7 of said proposed Directive reads: 'Non-genuine arrangements or a series thereof carried out for the essential purpose of obtaining a tax advantage that defeats the object or purpose of the otherwise applicable tax law provisions should be ignored for the purposes of calculating the corporate tax liability'.

84 Recommendation 2, indented quotation, COMMISSION RECOMMENDATION (EU) 2016/136 of 28 January 2016 on the implementation of measures against tax treaty abuse, C(2016) 271/2 [2016] OJ L25/67, p. 68. 
account all the circumstances, granting the benefit would be in accordance with the object and purpose of the relevant treaty provisions. The object and purpose of the relevant treaty provisions are quite different from commercial reasons that reflect economic reality. The wording 'genuine economic activity' was used by the CJEU in Cadbury Schweppes ${ }^{85}$ as a counterweight against the motive test in UK CFC legislation that was formulated identically to the PPT: the taxpayer had shown that the tax reduction was not 'one of the main purposes' of the transactions. ${ }^{86}$ That genuine economic activity must be based on objective factors which reflect real economic activity. ${ }^{87}$ The conclusion is that the GAAR in Article 6 ATAD uses wording that both refers to PPT and to well established CJEU case law, but from the construction of the rule it follows that the imperative of ignoring an arrangement in paragraph 1 is only on the agenda when the arrangement is non-genuine and does not reflect economic reality. The 'non-genuine' part of the wording is derived from Cadbury Schweppes and therefore should be interpreted like in Cadbury Schweppes, meaning that the arrangement can only be set aside when it is considered 'wholly artificial' in the opinion of the Court. That means that, in interpreting the GAAR in Article 6 ATAD, tentatively the conclusion may be that, at least where the fundamental freedoms are at stake in a cross-border situation, there is no contradiction for the application of secondary EU law and national tax law of the Member States between the GAAR in Article 6 ATAD and the position on tax avoidance clearly set out by the president of the CJEU in an authoritative article on 'The Concept of Abuse of Law in the Case Law of the European Court of Justice on Direct Taxation'. 88 This article makes it clear that in European law there is an essential difference in the concept between the fight against abuse of tax law and the fight against tax base erosion. In the former concept economic objectives are important and loss of revenue in a particular tax jurisdiction has to be accepted as a consequence; in the latter concept loss of revenue through base erosion is always more important regardless of the economic considerations. The title at the beginning of this chapter may suggest that finally abuse of tax law and tax base erosion are the same, but the conclusion is that, at least within the EU, they are not.

85 Case C-196/04 Cadbury Schweppes paras 54 and 66.

86 Ibid. para. 62.

87 Ibid. para. 67.

88 K. Lenaerts, 'The Concept of "Abuse of Law" in the Case Law of the European Court of Justice on Direct Taxation' (2015) 22 Maastricht Journal of European and Comparative Law 329. 